\title{
Exercise training in heart failure: role, prescription and program
}

\author{
Raymond Pranata,' Emir Yonas, ${ }^{2}$ Bambang B. Siswanto, ${ }^{3}$ Budhi S. Purwowiyoto ${ }^{3}$
}

'Faculty of Medicine, Universitas Pelita Harapan, Tangerang, Indonesia

${ }^{2}$ Faculty of Medicine, YARSI University,

Jakarta, Indonesia ${ }^{3}$ Department of Cardiology and Vascular Medicine, National Cardiovascular Centre Harapan Kita - Faculty of Medicine Universitas Indonesia, Jakarta, Indonesia
Heart failure is one of the most common cardiovascular diseases and is a final pathway of various cardiac pathologies. Exercise intolerance and dyspnea accompanied by deteriorating quality of life are common issues in those suffering from heart failure and may persist despite optimal medical therapy. Exercise training in heart failure theoretically helps to slow down the deterioration of the heart by antagonizing excess neurohormonal activity in heart failure, which translated into better functional capacity and quality of life. Exercise prescription is a mean of assessing and interpreting clinical information and applying the principles of training to develop an appropriate regimen and should be tailored to patient's clinical condition. Resistance training improves peak $\mathrm{VO}_{2}$, exercise capacity and quality of life in heart failure patients. Both continuous and interval exercise training are linked to better quality of life despite ambiguous results in mortality. The aim of this article is to discuss the benefits of exercise in patients with congestive heart failure, exercise prescription, and exercise program including high-intensity interval training, continuous training and resistance exercise.

(Indonesian J Cardiol. 2017;38:226-33)

Keywords: exercise, heart failure, rehabilitation, training, $\mathrm{VO}_{2}$ 


\title{
Latihan olahraga pada gagal jantung: peran, resep dan program
}

\author{
Raymond Pranata, ${ }^{1}$ Emir Yonas, ${ }^{2}$ Bambang B. Siswanto, ${ }^{3}$ Budhi S. Purwowiyoto ${ }^{3}$
}

Gagal jantung adalah salah satu penyakit kardiovaskular yang paling sering ditemui dan merupakan akhir daripada banyak jenis patologi jantung. Intoleransi olahraga dan sesak nafas disertai dengan memburuknya kualitas hidup merupakan beberapa masalah yang sering dihadapi oleh pasien gagal jantung, meskipun telah diberikan pengobatan yang optimal. Latihan olahraga pada gagal jantung secara teoritis dapat memperlambat menurunnya fungsi jantung dengan melawan aktivitas neurohormonal yang meningkat pada kondisi gagal jantung yang dicerminkan dengan kapasitas fungsional dan kualitas hidup yang lebih baik. Preskripsi olahraga meliputi pemeriksaan dan interpretasi dari informasi klinis dan aplikasi dari prinsip latihan untuk membentuk regimen yang sesuai dan harus di sesuaikan dengan keadaan klinis pasien. Latihan beban memperbaiki fungsi VO2 puncak, kapasitas olahraga dan kualitas hidup pada pasien dengan gagal jantung. Kedua metode olahraga baik secara kontinu ataupun interval dihubungkan dengan kualitas hidup yang lebih baik meskipun masih ambigu dalam hal mortalitas. Tujuan artikel ini adalah membahas manfaat latihan fisik pada pasien dengan gagal jantung kongestif, cara peresepan serta membahas program high intensity interval training, continuous training serta latihan beban.

(Indonesian J Cardiol. 2017;38:226-33)

Kata Kunci: olahraga, gagal jantung, rehabilitasi, latihan, $\mathrm{VO}_{2}$

\section{Introduction}

Heart failure (HF) is one of the most common cardiovascular disease, a final pathway of various cardiac pathologies and is associated with a high

'Faculty of Medicine, Universitas Pelita Harapan, Tangerang, Indonesia, ${ }^{2}$ Faculty of Medicine, YARSI University, Jakarta, Indonesia, ${ }^{3}$ Department of Cardiology and Vascular Medicine, National Cardiovascular Centre Harapan Kita - Faculty of Medicine Universitas Indonesia, Jakarta, Indonesia

\section{Correspondence:}

dr. Raymond Pranata, Faculty of Medicine, Universitas Pelita

Harapan, Tangerang, Indonesia, Tel. +6282II2918892

E-mail: raymond_pranat@hotmail.com mortality with a 5 years' survival rate of $35-55 \% .^{1-4}$ Exercise intolerance and dyspnea accompanied by deteriorating quality of life are a common issue in those suffering from heart failure and may persist despite optimal medical therapy. ${ }^{5}$

There were studies showing that a low physical fitness was associated with higher mortality rate while some disagreed, hence, the measure of physical fitness as a predictor of mortality was still ambiguous. ${ }^{6,7}$ The beneficial effects of physical training on physical fitness, cardiovascular function and quality of life are more established. ${ }^{8-12}$ One of the best predictor for cardiovascular and all-cause mortality in heart failure patients were peak aerobic capacity which is measured by peak oxygen uptake $\left(\mathrm{VO}_{2}\right.$ peak). ${ }^{13,14}$

Studies and guidelines advocate physical training 
in HF patients. ${ }^{15}$ Curiosity in interval training arose because of it's shorter exercise duration which may lead to a better compliance than continuous training. Studies were done to investigate whether the former or the latter was better. Exercise prescription formats may differ from one center to another. The aim of our article is to provide a summary of the role of exercise training in heart failure and how to prescribe the training program. We would also like to discuss about the training program including interval, continuous, and resistance training.

\section{Exercise training}

\section{Mechanism}

Sympathetic activity was dominant in HF patients due to excessive neurohormonal activation. This can be antagonized through exercise training which resulted in increased vagal activity (parasympathetic) and reduces products of renin-angiotensin-aldosterone axis. ${ }^{16}$ This leads to improved functional capacity, reduced peripheral vasoconstriction, and increases blood flow to skeletal muscles and peripheral part of the body culminating into improved exercise tolerance. There is also increased antioxidative activity because of reduction in vascular expression of NADPH oxidase and AT1, reducing production of reactive oxygen species leading to improved coronary vasodilation through the acetylcholine-mediated pathway and reduced Angiotensin-II-induced vasoconstriction. ${ }^{16}$
Regular exercise training can have an antiinflammatory effect marked by increased plasma levels of the anti-inflammatory cytokine IL-10 which can modulate the innate immune system, influencing macrophage and lymphocyte function. ${ }^{16}$ and it's oxidative capacity by improving activity of oxidative enzymes and mitochondrial content. This lead to an improvement in peak $\mathrm{VO}_{2}$ and lactate threshold and delayed onset of anaerobic metabolism.

Cardiomyocyte contractility and calcium sensitivity are improved by exercise training which translates into a better cardiac function. ${ }^{16}$ Preconditioning effects of brief ischemic episodes are maximized while stunning effects are minimized. Changes induced by exercise training was postulated to be effective in counteracting the progression of HF which lead to improvement in functional capacity and quality of life. ${ }^{16}$

\section{Exercise prescription}

Exercise prescription is a mean of assessing and interpreting clinical information and applying the principles of training to develop an appropriate regimen. ${ }^{17}$ It consists of mode, frequency, duration, and intensity. Table 1

Congestive heart failure (CHF) patients who participate in the rehabilitation programme have reduced mortality, morbidity, and rate of hospitalization. There are patient's factors to be considered for exercise training, although the risk of sudden death is extremely low, it is greater in CHF patients.

Table 1. Components of the exercise prescription for patients with heart Type

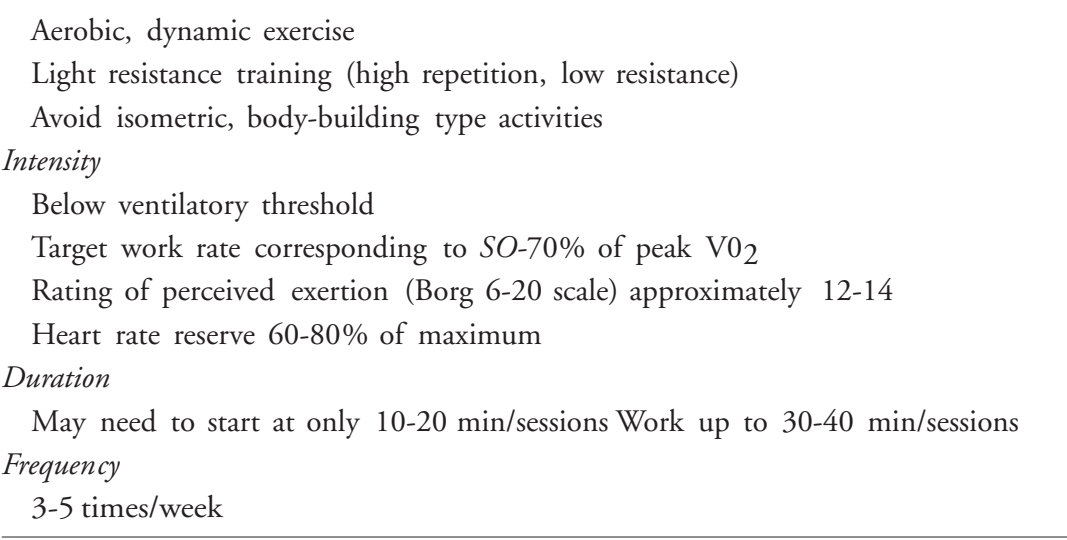

Failure from Principles of exercise prescription for patients with chronic heart failure. Heart Fail Rev. 2008. 13:61-68 
There are also medications that affect physiological response to exercises such as beta-blockers, devices such as implantable-cardioverter defibrillator and pacemakers. Coronary artery disease may also reduces exercise capacity. ${ }^{17}$ Most patients with reduced ejection fraction (EF) who are clinically stable and have reduced exercise tolerance are eligible for exercise programs. Exercise test should be done prior to training and attention to body weight, congestive symptoms and other clinical signs of decompensation are a must. (Table 2) In those with rhythm disturbances electrocardiographic (ECG) monitoring is often required. ${ }^{17}$

Training implies adaptations of the body to the demands placed on it. A training effect is best measured as an increase in maximal ventilatory oxygen uptake, however, an improvement in daily activities may also serve as an indicator. Major exercise components are frequency, intensity, duration, mode, and rate of progression. Increases in maximal oxygen uptake are achieved if the patient exercises dynamically (exercises that involves large muscles groups in rhythmically) for 15-60 minutes, 3-5 times/week at an intensity of 50-80\% of maximum capacity. Initially, the program is started with a target of 20 minutes at $50 \%$ capacity and gradually progressed in duration and intensity over time. (Table 3) Short warm-up and cool-down periods are important because of a slower cardiovascular adaptation to the work rate in CHF patients. ${ }^{17}$ The gold standard for exercise intensity assessment is by using cardiopulmonary exercise test, measuring $\mathrm{VO}_{2}$ peak or $\mathrm{VO}_{2}$ Reserve $\left(\mathrm{VO}_{2} \mathrm{R}\right) .{ }^{15}$ Training intensity is usually prescribed relative to the recommended training intensities are $40-50 \%$ at the starting point, increasing to $70-80 \%$ of the percentage $\mathrm{VO}_{2}$ peak or $\mathrm{VO}_{2} \mathrm{R} \cdot{ }^{15}$ However, it require facilities that not every hospital had a luxury of, hence Karvonen formula is a plausible alternative.. It is reliable for patients in normal sinus rhythm whose measurements of resting and maximum heart rates (HR) are accurate. Estimated training HR: intensity equivalent to the maximum in percent $x$ (Maximum $\mathrm{HR}$ - resting heart rate) + resting HR. For example, at a target intensity of $50 \%$, maximum HR 160 and resting HR of 80 . $50 \% \times(160-80)+80=120 \mathrm{bpm}$. Hence, the target is approximately $120 \mathrm{bpm} .{ }^{17}$ In those with irregular rhythm perceived exertion is used to guide training intensity. Training is started in the hospital, where direct monitoring and supervision is recommended especially early in the program. ${ }^{15}$

Table 2. Relative and absolute contraindications to exercise training among patients with stable chronic heart Relative contraindications

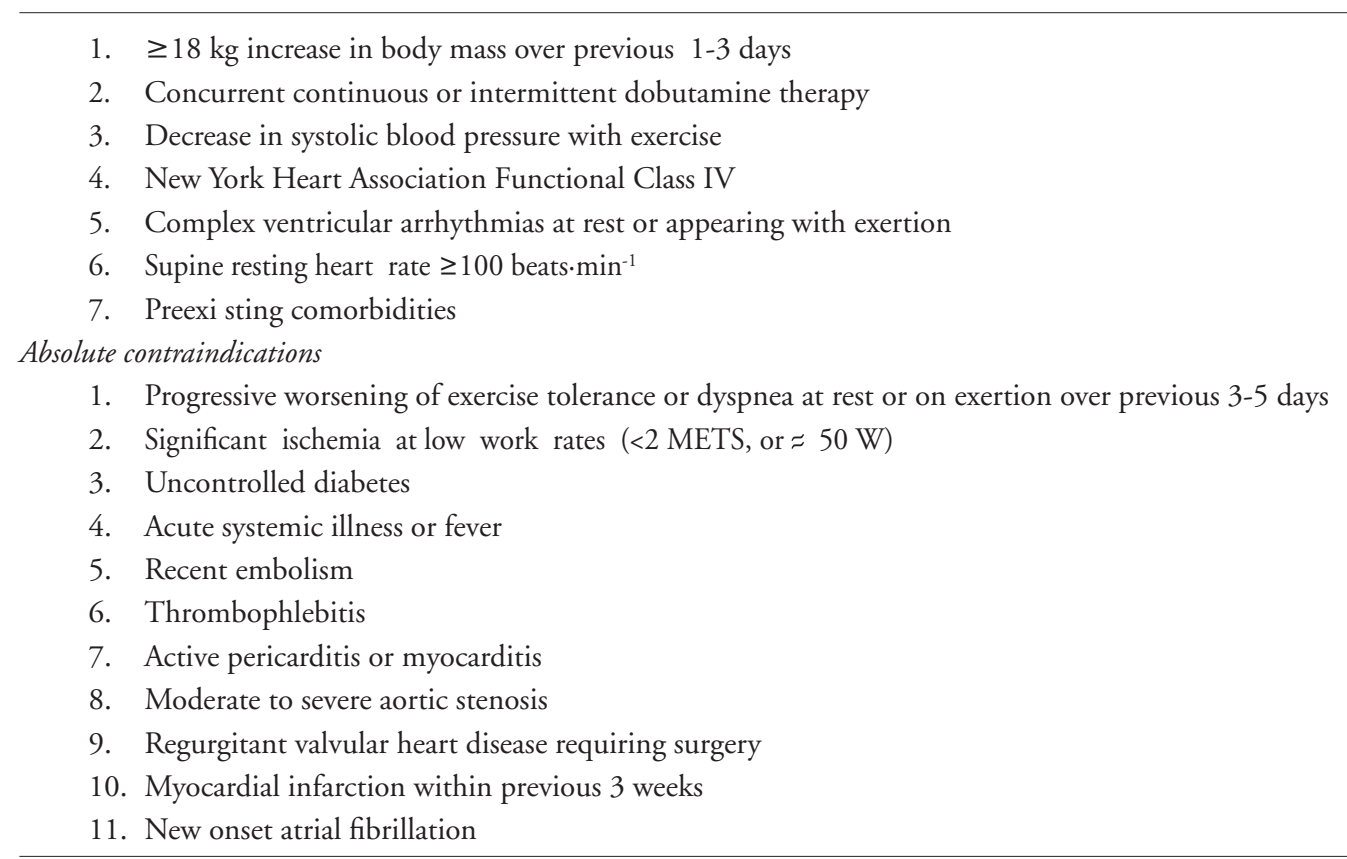

Failure from Principles of exercise prescription for patients with chronic heart failure. Heart Fail Rev. 2008. 13:61-68 
Table 3. Signs and symptoms below which an upper limit for exercise intensity should be set. Onset of angina or other symptoms of cardiovascular insufficiency

Plateau or decrease in systolic blood pressure, systolic blood pressure of $>250 \mathrm{mmHg}$ or diastolic blood pressure of $>115 \mathrm{mmHg}$ $\geq 1.0 \mathrm{~mm}$ ST-segment depression, horizontal or downsloping

Radionuclide evidence of left ventricular dysfunction or onset of moderate to severe wall motion abnormalities during exertion Increased frequency of ventricular dysrhythmias

Other significant ECG disturbances (e.g., 2 or 3 degree atrioventricular block, atrial fibrillation, supraventricular tachycardia, complex ventricular ectopy, etc.)

Other signs/symptoms of intolerance to exercise

The exercise heart rate generally should be at least 10 beats_min-1 below the heart rate associated with any of the referenced criteria. Other variables (e.g., the corresponding systolic blood pressure response and perceived exertion), however, also should be considered when establishing exercise intensity. From Principles of exercise prescription for patients with chronic heart failure. Heart Fail Rev. 2008. 13:61-68.

Stable and well-treated patients could initiate a home-based programme after a baseline exercise test with guidance and instructions. ${ }^{15}$ Follow up and monitoring is required.

\section{Interval versus Continuous training}

Continuous training (CT) is typically performed at moderate-to-high exercise intensities in steadystate conditions of aerobic energetic yield, which allows the patient to perform prolonged training sessions (up to $45-60 \mathrm{~min}$ duration). ${ }^{15}$ It is a safe, efficient and well tolerated by patients, hence it is recommended by heart failure association guidelines. In interval training (INT) protocol an alternate short bout (10-30 s) of moderate-high intensity (50-100\% peak exercise capacity) exercise, with a longer recovery (80-60 s) phase, performed at low or no workload. Recent trials demonstrated that INT especially high-intensity interval training (HIIT) to be more effective. ${ }^{18}$ Some evidence supported that interval training is more effective to improve left ventricular ejection fraction (LVEF) and left ventricular end diastolic diameter (LVEDD). ${ }^{19}$ A recent meta-analysis showed that an increase in exercise capacity, represented by the peak $\mathrm{VO}_{2}$, was similar between training modalities and the influence of a certain training modality on ventilation over carbon dioxide $\left(\mathrm{VE} / \mathrm{VCO}_{2}\right)$ slope was not found to be significantly different from other training modalities. Oxygen uptake efficiency slope (OUES) seemed to improve significantly with INT compared to CT (only one study). Quality of life seems to improve significantly with combined interval and strength training. ${ }^{19}$ Another metaanalysis showed that in clinically stable heart failure with reduced ejection fraction patients, INT is more effective than $\mathrm{CT}$ for improving peak $\mathrm{VO}_{2}$ but not the LVEF at rest. ${ }^{20}$ Adherence to exercise training is very important and this is often problematic in HF due to time-constraints and lack of energy. ${ }^{21,22}$ A HIIT training with lower training frequency and high-intensity intervals of moderate duration might address these two major factors of non-compliance, hence improving adherence. A low-frequency HIT with high-intensity intervals of moderate duration is feasible and successful in improving fitness. These might be a component of optimal exercise protocol for HF patients to achieve long-term benefits and adherence in the future. ${ }^{22}$ The risk of cardiovascular events concerning HIT has been demonstrated to be low in the patients with coronary artery disease, however, its safety has not been confirmed in those with HF reduced EF (HFrEF) in a largescale investigation. ${ }^{23}$ Most patients with HFrEF have relatively impaired exercise hemodynamics in the initial sessions of exercise training. ${ }^{23}$ There was a trial evaluating modified HIT (CT in the first 12 sessions and followed by 24 HIT sessions) compared to optimal medical treatment only in which supervised continuous aerobic training at ventilator anaerobic threshold for $50 \mathrm{~min} /$ day, 3 days/week for 4 weeks, and then 3-min intervals at 40 and $80 \% \mathrm{VO}_{2}$ reserve for $50 \mathrm{~min} /$ day, 3 days/ week for 8 weeks demonstrated an improved peak cardiac pumping capacity with reducing cardiac after-load and simultaneously increases ventilation efficiency during exercise in patients with HFrEF, giving time for adaption in initial sessions before proceeding to HIIT. ${ }^{23}$ Any exercise training program seems sufficient to improve the prognosis, quality of life and anatomic function. ${ }^{19}$ 


\section{Resistance training}

Muscle atrophy has been demonstrated to be a hallmark of $\mathrm{CHF}$, resistance training aims to train peripheral muscles effectively without producing great cardiovascular stress. ${ }^{24}$ Resistance training (RST) is recommended to restore muscular strength as a complement to aerobic training. ${ }^{24}$ Dynamic resistance training, based on the principles of interval training, has recently been established as a safe and effective mode of exercise in patients with CHF. It was performed slowly, on specific machines at an intensity usually in the range of $50-60 \%$ of one repetition maximum (1-RM); work phases are of short duration (< or $=60$ seconds) and should be followed by an adequate recovery period (work/recovery ratio $>1: 2$ ). ${ }^{24}$ Patients with a low cardiac reserve can use small free weights $(0.5$, 1 or $3 \mathrm{~kg}$ ), elastic bands with 8-10 repetitions, or they can perform resistance exercises in a segmental fashion. ${ }^{24}$ Resistance only or combined training improves peak $\mathrm{VO}_{2}$, quality of life and walking performance in heart failure patients. ${ }^{25}$ According to the consensus of exercise training in heart failure, for maximal safety, initiation of an RST programme must be individually adapted to the patient by an experienced exercise therapist under medical supervision and each patient must be individually introduced into the training regimen. where three progressive steps are described ${ }^{15}$ the first is 'Instruction phase' in which a preliminary step should be performed, to get the patient well accustomed to the modality of the exercise, and for intermuscular co-ordination and physical perception. These preparatory exercises must be conducted slowly, without or at a very low resistance (<30\% 1-RM) until the patient is confident with the course of the movements. Next is 'Resistance/endurance phase', RST can be started with a high number of repetitions (12-25) and a low intensity (30-40\% 1-RM), corresponding rather to a combination of endurance and resistance because of a low hemodynamic load. When the patient is confident with the exercise, he can proceed to the next phase (strength phase) Strength phase' in which RST is performed at a higher intensity (40-60\% 1-RM) in order to increase muscle mass.

\section{Conclusion}

In conclusion, exercise training counteracts the progression of devastating compensatory mechanisms of HF, leading to improvement in functional capacity and quality of life. According to ESC Guidelines for the diagnosis and treatment of acute and chronic heart failure, regular aerobic exercise is Class I recommendation to improve functional capacity, symptoms and reduce risk of HF hospitalization (in stable HFrEF). ${ }^{26}$ Exercise prescription is a mean of assessing and interpreting clinical information and applying the principles of training to develop an appropriate regimen. An exercise program should be tailored to patient's clinical condition. Resistance training is also important as muscle atrophy is a concern in $\mathrm{CHF}$, it improves peak $\mathrm{VO}_{2}$, quality of life and walking performance in heart failure patients. Adherence is central to training for the best result. Any exercise training program, whether INT, CMT, combined INT-strength or CMT-strength seems sufficient to improve the prognosis, quality of life and anatomic function. The most important thing is that the patient can adhere to the program given.

\section{Conflicts of interest}

The authors affirm no conflict of interest in this study

\section{Acknowledgment}

Not Applicable

\section{Abbreviations}

\section{CT: Continuous Training}

CHF: Congestive Heart Failure

LVEDD: Left Ventricular End Diastolic Diameter

LVEF: Left Ventricular Ejection Fration

HF: Heart Failure

HFrEF: Heart Failure reduced Ejection Fraction

HIIT: High-Intensity Interval Training

INT: Interval Training

RM: Repetition Maximum

RST: Resistance Training

VE/VCO2: Ventilation over carbon dioxide

VO2R: VO2 Reserve

\section{Availability of data and material}

The datasets supporting the conclusions of this article are included in the article 


\section{Competing interests}

None Declared

\section{Funding}

\section{None \\ Authors' contributions}

$\mathrm{RP}$ and EY drafted the manuscript and perform extensive research. BBS and BSP supervise and give invaluable expertise to this manuscript.

\section{Acknowledgements}

\section{Not Applicable \\ References}

1. McCullough PA, Philbin EF, Spertus JA, Kaatz S, Sandberg KR, Weaver WD, et al. (2002) Confirmation of a heart failure epidemic: findings from the Resource Utilization Among Congestive Heart Failure (REACH) study. J Am Coll Cardiol 39: 60-69. PMID: 11755288

2. Bleumink GS, Knetsch AM, Sturkenboom MC, Straus SM, Hofman A, Deckers JW, et al. (2004) Quantifying the heart failure epidemic: prevalence, incidence rate, lifetime risk and prognosis of heart failure The Rotterdam Study. Eur Heart J 25: 1614-1619. PMID: 15351160

3. Levy D, Kenchaiah S, Larson MG, Benjamin EJ, Kupka MJ, Ho KK, et al. (2002) Long-term trends in the incidence of and survival with heart failure. N Engl J Med 347: 1397-1402.

4. Zarrinkoub R, Wettermark B, Wandell P, Mejhert M, Szulkin R, Ljunggren $G$, et al. (2013) The epidemiology of heart failure, based on data for 2.1 million inhabitants in Sweden. Eur J Heart Fail 15: 995-1002.

5. Clark AL, Cleland JG (2005) Beta-blockers, exercise, and ventilation in chronic heart failure. J Card Fail 11:340-342

6. Cahalin LP, Chase P, Arena R, Myers J, Bensimhon D, Peberdy MA, et al. (2013) A meta-analysis of the prognostic significance of cardiopulmonary exercise testing in patients with heart failure. Heart Fail Rev 18: 79-94.

7. Myers J, Gullestad L, Vagelos R, Do D, Bellin D, Ross H, et al. (1998) Clinical, hemodynamic, and cardiopulmonary exercise test determinants of survival in patients referred for evaluation of heart failure. Ann Intern Med 129: 286-293.

8. van Tol BA, Huijsmans RJ, Kroon DW, Schothorst M, Kwakkel G (2006) Effects of exercise training on cardiac performance, exercise capacity and quality of life in patients with heart failure: a meta-analysis. Eur J Heart Fail 8: 841-850.

9. Haykowsky MJ, Liang Y, Pechter D, Jones LW, McAlister FA,
Clark AM (2007) A meta-analysis of the effect of exercise training on left ventricular remodeling in heart failure patients: the benefit depends on the type of training performed. J Am Coll Cardiol 49: 2329-2336.

10. Hambrecht R, Hilbrich L, Erbs S, Gielen S, Fiehn E, Schoene N, et al. (2000) Correction of endothelial dysfunction in chronic heart failure: additional effects of exercise training and oral Larginine supplementation. J Am Coll Cardiol 35: 706-713.

11. Linke A, Schoene N, Gielen S, Hofer J, Erbs S, Schuler G, et al. (2001) Endothelial dysfunction in patients with chronic heart failure: systemic effects of lower-limb exercise training. J Am Coll Cardiol 37: 392-397.

12. Lavie CJ, Arena R, Swift DL, Johannsen NM, Sui X, Lee DC, et al. (2015) Exercise and the Cardiovascular System: Clinical Science and Cardiovascular Outcomes. Circ Res 117: 207-219.

13. Myers J, Prakash M, Froelicher V, Do D, Partington S, Atwood JE. Exercise capacity and mortality among men referred for exercise testing. N Engl J Med. 2002;346:793-801.

14. Kavanagh T, Mertens DJ, Hamm LF, Beyene J, Kennedy J, Corey P, Shephard RJ. Prediction of long-term prognosis in 12169 men referred for cardiac rehabilitation. Circulation. 2002;106:666-671.

15. Piepoli MF, Conraads V, Corra U, Dickstein K, Francis DP, Jaarsma T, et al. (2011) Exercise training in heart failure: from theory to practice. A consensus document of the Heart Failure Association and the European Association for Cardiovascular Prevention and Rehabilitation. Eur J Heart Fail 13: 347-357.

16. Piepoli M. F. Exercise training in chronic heart failure: mechanisms and therapies. Netherlands Heart Journal. 2013;21(2):8590.

17. Myers J. Principles of exercise prescription for patients with chronic heart failure. Heart Fail Rev. 2008. 13:61-68

18. Piepoli, M.F., Conraads, V., Corra, U., Dickstein, K., Francis, D.P., Jaarsma, T. et al. Exercise training in heart failure: from theory to practice. A consensus document of the Heart Failure Association and the European Association for Cardiovascular Prevention and Rehabilitation. Eur. J. Heart Fail. 2011; 13:347357

19. Cornelis J, Beckers P, Taeymans J, et al. Comparing exercise training modalities in heart failure: A systematic review and meta-analysis. Int J Cardiol. 2016 Oct 15;221:867-76.

20. Haykowsky MJ, Timmons MP, Kruger C, McNeely M, Taylor DA, Clark AM (2013) Meta-analysis of aerobic interval training on exercise capacity and systolic function in patients with heart failure and reduced ejection fractions. Am J Cardiol 111: 1466-1469.

21. Barbour KA, Miller NH (2008) Adherence to exercise training in heart failure: a review. Heart Fail Rev 13: 81-89.

22. Benda NM, Seeger JP, Stevens GG, et al. Effects of high-intensity 
Pranata $R$ et al: Exercise training in heart failure: role, prescription and program

interval training versus continuous training on physical fitness, cardiovascular function and quality of life in heart failure patients. PLoS One. 2015 Oct 30;10(10):e0141256.

23. Huang SC, Wong MK, Lin PJ, et al. Modified high-intensity interval training increases peak cardiac power output in patients with heart failure. Eur J Appl Physiol. 2014 Sep;114(9):185362.

24. Volaklis KA, Tokmakidis SP (2005) Resistance exercise training in patients with heart failure. Sports Med 35:1085-1093

25. Jewiss D, Ostman C, Smart NA. Resistance only or combined training improves peak $\mathrm{VO}_{2}$, quality of life and walking performance in heart failure patients. Int J Cardiol. $2016 \mathrm{Oct}$ 15;221:674-81

26. Ponikowski P, Voors AA, Anker SD, et al. 2016 ESC Guidelines for the diagnosis and treatment of acute and chronic heart failure: The Task Force for the diagnosis and treatment of acute and chronic heart failure of the European Society of Cardiology (ESC). Developed with the special contribution of the Heart Failure Association (HFA) of the ESC. Eur J Heart Fail. 2016;18(8):891-975. 